\title{
AIDS REVIEW: Inventing AIDS
}

\author{
Lynne Segal
}

Inventing AIDS by Cindy Patton, London: Routledge, 1991, £9.99 Pbk, ISBN 0415902576.

Ignorance, fear, brutality and neglect are not the main themes of this new book on AIDS, but something a little more insidious: the liberal and above all scientific discourses of AIDS. It is here, as well as in the many more obvious abuses, that power, discrimination, homophobia, racism and prejudice reside. It is good to see a new book from Cindy Patton, one of the leading and most tireless activists, thinkers and writers about AIDS in the US. Her earlier book, Sex and Germs (South End Press), back in 1985, was one of the first and clearest attempts to sort out the biological, psychological, social and political issues surrounding the HIV virus, and the orchestrated epidemic of fear and hatred with which so many responded to it, as well as one of the first to broadcast gay and lesbian resistance and practices of safe sex in the USA. In her most recent book, Patton moves on to consider the apparently more progressive responses of 'the AIDS service industry' in the US, suggesting that the strictly 'scientific' approach it adopts has led to serious weaknesses in its educational strategies, as well as further discrimination against gays, women and black people.

From the mid-1980s in the USA, Patton argues, the newly emerging government-funded and professionalized AIDS services began to dominate and erase from public knowledge the former history of AIDS activism, initiated largely by gay communities, and to a lesser extent IV drug-taking communities, between 1981 and 1985. This new AIDS industry emerging in the US, with its own goals and perspectives based on ideas of 'victims', 'volunteers' and 'experts', contrasted sharply with the earlier politicized and self-empowering AIDS activism. In the new AIDS industry, care for people with AIDS replicated the existing 
irrational delivery of health care in the USA, relying on volunteers and charity work, and deepening class and race discriminations - now greatly exacerbated by Reaganite cuts in social services. For example, rewriting AIDS activism as altruism, meant both diffusing the political significance of community organizing, by promoting the 'good works' of gay male volunteers and the white middle-class women who tended to work with them, and blaming black and drug-using 'communities' for failing to provide for their own care.

Patton also criticizes what she sees as the weaknesses of the new professional AIDS-education policies. Between 1985 and 1989, for example, government-funded AIDS education was directed not at those, like drug users, most immediately vulnerable to HIV infection, but at those, like students, most likely to accept the middle-class view of AIDS as a tragic disease which medicine would one day cure. More significantly, rather than emphasizing the importance of safer-sex practices, illustrating their possible diversity and pleasures, and rather than promoting safe drug-taking routines, professional programmes in the US have concentrated instead on encouraging the idea of 'voluntary' HIV antibody testing as its primary educational strategy for dealing with AIDS. This is even though, Patton adds, widespread testing programmes have been internationally widely rejected as expensive, ineffective and misleading as an educational strategy.

One central theme of Patton's analysis is thus that professionalized education programmes have ignored the success of earlier AIDS activists which suggest the long-term value of participatory projects, with local groups generating their own strategies and thus changing behaviour as a form of resistance and community building. Instead, emphasis is placed on more neutral strategies like widespread testing programmes and the idea that information, by itself, will generate behaviour change. Yet there is now 'general scientific consensus' that there is no predictable relationship even between knowledge of HIV antibody status and behaviour change. Moreover, when 'safe sex' is promoted by the new professional groups, it loses the inventiveness and creativity which gay men had invested in it as a positive sexual choice, clearly indicating those practices which are risky and those many other sexual practices which are safe. Safer sex becomes instead merely reference to condom use and reduction in number of partners. Especially with its targeting of heterosexual groups in 1986/7, the professional literature on 'safe sex', rather than challenging vaginal intercourse as 'the sex act', reduced all sex to penile performance - with or without condoms. Meanwhile the passing of discriminatory laws like the Helms Amendment has meant a prohibition on government funding for any sex-positive education, and increased levels of homophobia in the US.

The scientific biases of the AIDS industry have thus involved the remedicalization of sexuality in professional AIDS discourses which, in the process, still rely upon all the old conventional gendered and racist paradigms and metaphors of sex. Studying the literature on AIDS in 
Africa, for instance, Patton exposes both its dependence on centuries of stereotyped racist perception, constructing 'African AIDS' as something altogether different, more virulent and terrifying than AIDS in the West, and enabling callous and unethical use of African subjects for empirical testing procedures. Yet Patton is not without some optimism, despite what she sees as the lethal failures of Western science when educating people about AIDS to provide useful practical advice about either sex or drugs:

There are, despite all this, some very exciting projects underway in communities disenfranchised by the white middle-class AIDS industry in communities of color, among IV drug users, among sex workers, in communities in post-colonial and post-revolutionary nations. These projects rely on community involvement, are open-ended, and view the process of AIDS education as important in determining how AIDS will be perceived and how well behavior changes will succeed. But these projects are under funded and in danger of the absorption which homogenised the earlier projects by and for the gay male community.

One disappointment of her book for feminists is that Patton frequently mentions, but rarely focuses sufficiently directly upon, the specific gender issues around HIV/AIDS discourse and safer-sex practices. For example, she says clearly enough that safer-sex practices in gay male cultures can work because they assume a rough equality between sexual partners - both could be equally responsible for ensuring safer sex occurred, an assumption which clearly cannot be made for heterosexual couplings. But Patton does not explore more fully how women can work to overcome this in their own educational programmes or individual and collective practices. A theme for her next book, perhaps? Meanwhile, there is plenty to chew over in this one. 